Disclosure of Interest: J. Stone Grant/research support from: Genetech/Roche, Xencor, Consultant for: Genentech/Roche, Xencor, Z. Wallace: None declared, C. Perugino: None declared, A. Fernandes: None declared, P. Patel: None declared, P. Foster Shareholder of: Full time employee of Xencor, Employee of: Full time employee of Xencor, D. Zack Shareholder of: Full time employee of Xencor, Employee of: Full time employee of Xencor

DOI: 10.1136/annrheumdis-2017-eular.3301

\section{FRI0589 CANCER IS FREQUENT IN PATIENTS WITH ANTICENTROMERE PATTERN}

C. Vázquez-Triñanes $^{1}{ }^{1}$, V. Alende ${ }^{2}$, E. González $^{3}$, R. Lorenzo $^{4}$, T. Caínzos $^{5}$, L. González ${ }^{6}$, S. Rodríguez ${ }^{6}$, B. Sopeña ${ }^{2}$ on behalf of Círculo de estudio de las enfermedades autoinmunes de Galicia (CEAG). ${ }^{1}$ Systemic Autoimmune Diseases and Thrombosis Unit, H. Álvaro Cunqueiro, Vigo; ${ }^{2}$ Hospital Clínico Universitario de Santiago, Santiago: ${ }^{3}$ Complejo Hospitalario de Ourense, Ourense; ${ }^{4} \mathrm{H}$. Álvaro Cunqueiro, Vigo; ${ }^{5} \mathrm{Hospital}$ Arquitecto Marcide, Ferrol; ${ }^{6} \mathrm{H}$. Povisa SA, Vigo, Spain

Background: Anti-centromere pattern (ACA) is infrequently seen among antinuclear antibodies (ANA) detected by indirect immunofluorescence (IFI). ACA is associated with systemic autoimmune diseases (SAD), especially systemic sclerosis (SSc). Some studies had recently related ACA with cancer, mostly with breast and lung cancer [1]. However, most published series of patients with ACA lack information about cancer occurrence. A prevalence of cancer of $11.1 \%$ was the only reported data, on a series of 45 unselected patients with ACA [2]

Objectives: Our aim was to study the prevalence of cancer in the largest series of patients with ACA, with a long follow-up. Our second objective was to make a cohort to calculate the incidence of cancer and to try to identify risk markers of cancer in these patients

Methods: We included consecutive patients with at least 2 positive determinations of ANA with ACA by IFI on Hep2 cells between January 1st of 2011 and June 30th of 2015 in 6 Galician hospitals. The authors reviewed each patient's chart to determine the presence of cancer and its type among numerous variables. Then, patients with cancer at the moment of the first positive determination of ANA with ACA were excluded. We checked the presence of any tumour in patients of this cohort at the end of follow-up to calculate the incidence of cancer. Finally, we compared patients with and without cancer by multivariate analysis, with the SPSS 20.0. The ethics committees of each hospital approved the study and patients gave their consent

Results: 369 patients with ACA were studied, of which 333 were women (90.2\%), with a mean age of 64.7 years (range: $22-92$ ). The mean follow-up from the first positive ACA determination was 67.6 months. 283 patients $(76.7 \%)$ had a SAD: $46.3 \%$ SSc $(79 \%$ of whom were Ic-SSc), $8.13 \%$ primary biliary cholangitis, $7.05 \%$ Sjögren's syndrome, $4.6 \%$ autoimmune hepatitis and 11 other SAD (polyarthritis, SLE, Raynaud phenomenon, sarcoidosis, mixed connective tissue disease, etc). 45 of these patients $(15.9 \%)$ had any overlap syndrome. 39 patients had cancer at some time $(10.6 \%), 3$ of them with 2 types of cancer. The most frequent were: breast in $9(23.1 \%)$, lung in $5(11 \%), \mathrm{NHL}$ in $5(11 \%)$ and colorectal in $4(10.3 \%)$. Cancer preceded the diagnosis of ACA in 19 patients (48.7\%), with a mean time to diagnosis of 9.1 years (range 1-18). In the cohort of 350 patients with ACA the incidence was 1.14 per 100 patients per year (n 20). The mean time to diagnosis of cancer was 7.3years (range 1-27). The oldest age was the only risk marker of cancer identified $(70.8 \pm 13.29$ years vs. $63.9 \pm 14.32, p 0.005)$. There were no differences in the other variables analysed including sex, tobacco, diagnosis of SAD, capillaroscopy pattern, ANA titrations and mortality

Conclusions: Cancer was frequent in patients with ACA, with a prevalence of $10.6 \%$ and incidence of 1.14 per 100 patients per year. The only risk marker of cancer identified in this population was the oldest age

\section{References:}

[1] Briasoulis E, Kamposioras K, Tzovaras V et al. CENP-B specific anticentromere autoantibodies heralding small-cell lung cancer. A case study and review of the literature. Lung cancer 2008;60:302-306.

[2] Zuber M, Gotzen R, Filler I. Clinical correlation of anticentromere antibodies. Clinical rheumatology 1994;13(3):427-432.

Disclosure of Interest: None declared

DOI: 10.1136/annrheumdis-2017-eular.4455

\section{FRI0590 SOLUBLE INTERLEUKIN-2 RECEPTOR LEVELS REFLECT DISEASE ACTIVITY IN IGG4-RELATED DISEASE AND PRIMARY SJÖGREN'S SYNDROME}

M. Akiyama, T. Sasaki, Y. Kaneko, H. Yasuoka, K. Suzuki, K. Yamaoka, T. Takeuchi. Division of Rheumatology, Department of Internal Medicine, Keio University School of Medicine, Tokyo, Japan

Background: Soluble interleukin-2 receptor (sIL-2R) is known as an indicator for activation status of lymphocytes and could be a potential biomarker for disease activity of lymphoproliferative disorders and autoimmune diseases.

Objectives: The aim of this study was to examine the association of SIL-2R with disease activity in patients with lgG4-related disease (IgG4-RD) and primary Sjögren's syndrome (pSS).

Methods: Consecutive 45 patients with active, untreated IgG4-RD, 117 patients with pSS, and 10 patients with sicca syndrome (subjects with xerostomia with neither anti-SSA/SSB antibodies nor lymphocytic infiltration by lip biopsy) were enrolled. Disease activity of IgG4-RD and pSS was determined based on the IgG4-RD responder index (IgG4-RD RI) score and the EULAR Sjögren's Syndrome Disease Activity Index (ESSDAI) score, respectively. The association of SIL-2R with disease activity was analyzed.

Results: The levels of sIL-2R and serum IgG were significantly higher in both $\operatorname{lgG} 4-R D(709 \mathrm{U} / \mathrm{mL}$, and $1988 \mathrm{mg} / \mathrm{dL})$ and $\mathrm{pSS}(464 \mathrm{U} / \mathrm{mL}$, and $1851 \mathrm{mg} / \mathrm{dL})$ compared to sicca syndrome $(276 \mathrm{U} / \mathrm{mL}$, and $1255 \mathrm{mg} / \mathrm{dL})$. Serum levels of $\mathrm{lgG} 4$, $\operatorname{lgE}$, and circulating eosinophil counts were significantly higher in IgG4-RD (552mg/dL, $732 \mathrm{IU} / \mathrm{mL}$, and $\left.366 / \mathrm{mm}^{3}\right)$ compared to $\mathrm{pSS}(37 \mathrm{mg} / \mathrm{dL}, 216 \mathrm{IU} / \mathrm{mL}$, and $157 / \mathrm{mm}^{3}$ ) and sicca syndrome $\left(45 \mathrm{mg} / \mathrm{dL}, 132 \mathrm{IU} / \mathrm{mL}\right.$, and $\left.137 / \mathrm{mm}^{3}\right)$. On the other hand, the levels of serum $\operatorname{lgA}$ and $\operatorname{lgM}$ were significantly higher in pSS (312mg/dL, and $112 \mathrm{mg} / \mathrm{dL})$ compared to $\mathrm{lgG} 4-\mathrm{RD}(182 \mathrm{mg} / \mathrm{dL}$ and $81 \mathrm{mg} / \mathrm{dL})$ and sicca syndrome $(228 \mathrm{mg} / \mathrm{dL}$ and $78 \mathrm{mg} / \mathrm{dL})$. The levels of serum C-reactive protein, lactate dehydrogenase, $\mathrm{CH} 50, \mathrm{CC}$ chemokine ligand (CCL17)/thymus and activation-regulated chemokines (TARC) were not different among the three groups. In patients with IgG4-RD, the baseline IgG4-RD RI scores significantly correlated with the levels of sIL-2R $(\rho=0.715, p<0.0001)$, serum IgG $(\rho=0.672$, $p<0.0001)$ and IgG4 $(\rho=0.632, p<0.0001)$, but not serum IgE levels $(\rho=0.290$, $p=0.082)$ and circulating eosinophil counts $(\rho=0.149, p=0.335)$. In patients with pSS, the ESSDAI scores significantly correlated with the levels of sIL-2R ( $\rho=0.615$, $p<0.0001)$ and serum $\operatorname{lgG}(\rho=0.627, p<0.0001)$, but not the levels of serum $\lg A$ $(\rho=0.169, p=0.073)$ and $\operatorname{lgM}(\rho=0.133, p=0.157)$. Furthermore, the number of affected organs positively correlated with sIL-2R levels in both IgG4-RD $(\rho=0.725$, $p<0.0001)$ and pSS $(\rho=0.559, \quad p<0.0001)$. Receiver operating characteristic curve analysis demonstrated that $\mathrm{SIL-2R}$ was the most distinguishable biomarker for the presence of extra-dacryosialadenitis lesions in patients with IgG4-RD, compared to serum IgG and IgG4, with a cut-off value of $424 \mathrm{U} / \mathrm{mL}$ (AUC=0.917, $p<0.0001)$, and in patients with pSS with $513 \mathrm{U} / \mathrm{mL}(\mathrm{AUC}=0.894, p<0.0001)$. The sIL-2R levels in patients with IgG4-RD decreased significantly after glucocorticoid treatment. Notably, the cases which could be followed up at disease relapse or exacerbation showed the re-elevation of SIL-2R levels.

Conclusions: Soluble IL-2R level is a biomarker for disease activity, in particular for the extent of organ involvements and extra-dacryosialadenitis lesions in patients with IgG4-RD and pSS. Furthermore, sIL-2R level could be useful for longitudinal disease monitoring in patients with IgG4-RD.

Acknowledgements: We sincerely thank all the physicians and others caring for the patients enrolled in this study.

Disclosure of Interest: None declared

DOI: 10.1136/annrheumdis-2017-eular.4220

\section{FRI0591 RISK FACTORS FOR DISEASE RELAPSE IN IGG4-RELATED DISEASE FOLLOWING GLUCOCORTICOIDS TREATMENT}

T. Sasaki, M. Akiyama, Y. Kaneko, H. Yasuoka, K. Suzuki, K. Yamaoka, T. Takeuchi. Division of Rheumatology, Department of Internal Medicine, Keio University School of Medicine, Tokyo, Japan

Background: IgG4-related disease (IgG4-RD) is a fibroinflammatory disease characterized by elevated serum IgG4 and infiltration of $\operatorname{lgG} 4^{+}$plasma cells at affected sites. The patients with IgG4-RD respond well to glucocorticoids (GCs), but one-third of the patients experience disease relapse during tapering of GCs (1). The risk factors for disease relapse following treatment are unclear.

Objectives: The aim of this study was to identify the risk factors of disease relapse following reduction of GCs therapy.

Methods: Consecutive, newly diagnosed patients with IgG4-RD who were followed over 6 months after treatment with GCs in our department were enrolled. The patients were divided into two groups according to the presence or absence of disease relapse. Disease relapse was defined as the appearance of new lesions or the re-enlargement of involved organs that required dose-increase of GCs. Patient characteristics and laboratory findings at diagnosis were compared and receiver operating characteristic curve analysis was performed to identify the relevant predictive factors of disease relapse.

Results: A total of 34 patients were included and all patients were treated with GCs alone as initial treatment. Ten patients (29.4\%) experienced relapses during GCs dose tapering which was at 16.0 months (median) after GCs initiation. No difference was found in age, sex, body weight, and disease duration between the two groups. The observation periods and the initial/last GCs dose were also not different. However, serum lgG4 (939 vs $450 \mathrm{mg} / \mathrm{dl}, \mathrm{p}=0.008$ ), serum IgG4/lgG ratio $(0.35$ vs $0.24 p=0.046)$, soluble $I L-2$ receptor $(907 \mathrm{vs} 677 \mathrm{U} / \mathrm{ml}, \mathrm{p}=0.032$ ) and number of organ involvement ( 4.3 vs $3.0, p=0.028)$ were significantly higher in patients with relapse than those without, while the level of $\operatorname{lgA}(135 \mathrm{vs} 205 \mathrm{mg} / \mathrm{dl}$, $\mathrm{p}=0.015)$ and $\operatorname{lgM}$ ( $60 \mathrm{vs} 91 \mathrm{mg} / \mathrm{dl}, \mathrm{p}=0.038$ ) were significantly lower in the patients with relapse. IgG4 decreased to a comparable level in both groups after GCs treatment ( $200 \mathrm{vs} 91 \mathrm{mg} / \mathrm{dl}, \mathrm{p}=0.124)$, but increased in the relapse group afterward ( $387 \mathrm{vs} 115 \mathrm{mg} / \mathrm{dl}$ at last observation, $p=0.048$ ). The predictive values (sensitivity, specificity) at IgG4-RD diagnosis for relapse were as follows; serum IgG4 570 $\mathrm{mg} / \mathrm{dl}(90.0 \%, 75.0 \%)$, IgG4/lgG 0.31 (70.0\%, 79.2\%), soluble IL-2 receptor 470 $\mathrm{IU} / \mathrm{ml}(100.0 \%, 54.5 \%)$, the number of affected organs of four $(80.0 \%, 70.8 \%)$, IgA $100 \mathrm{mg} / \mathrm{dl}(50.0 \%, 100.0 \%)$ and $\operatorname{lgM} 60 \mathrm{mg} / \mathrm{dl}(80.0 \%, 75.0 \%)$ (Figure 1$)$. Conclusions: Higher serum IgG4, soluble IL-2 receptor, and the number of affected organs and lower levels of serum $\lg \mathrm{A}$ and $\operatorname{lgM}$ at baseline indicate 